\title{
Removal of a broken dental needle in the pterygomandibular space using an image intensifier: two case reports
}

\author{
- Paulo Rogério Corrêa Couto Centro Universitário Tabosa de Almeida ASCES-UNITA, Caruaru, PE, Brazil \\ - Rafael do Nascimento Silva Centro Universitário Tabosa de Almeida ASCES-UNITA, Caruaru, PE, Brazil \\ - Rafael de Sousa Carvalho Sabóia Centro Universitário Tabosa de Almeida ASCES-UNITA, Caruaru, PE, Brazi \\ - Airton Vieira Leite Segundo Faculdade de Medicina do Sertão, Caruaru, PE, Brazil
}

\begin{abstract}
ABSTRACT | Introduction: Accidents and complications are elements that can occasionally be associated with the procedures realized within work dentist environment. Among some accidents related to dental practice, needle fracture during local anesthesia is noteworthy due to its rarity. Objective: This work seeks to report two cases of removal of a broken dental needle in the pterygomandibular space using an image intensifier. Material and Methods: In both cases, the accident happened during an inferior alveolar nerve block. The surgeons requested image exams to locate the objects using general anesthesia. In the surgery, a transoral incision was made to remove the broken needle from the pterygomandibular space, guided by an image intensifier. Results: Both surgeries were a success. The broken needles were found quickly with the use of the image intensifier, and no postoperative complications were observed. Conclusion: The correct assessment of fractured dental position is essential for its removal. The use of the image intensifier has been showing advantages, such as offering fast transoperative dynamic images and at different angles, thus providing opportunity for calmer surgery and with less risk for the patient and the operator.
\end{abstract}

DESCRIPTORS | Needle; Fracture; Local anesthesia; Image.

RESUMO | Remoção de agulha dentária quebrada no espaço pterigomandibular usando um intensificador de imagem: relato de dois casos • Introdução: Acidentes e complicações são elementos que ocasionalmente podem estar associados a procedimentos realizados em ambiente de trabalho odontológico. Dentre alguns acidentes relacionados à prática odontológica, a fratura por agulha durante a anestesia local destaca-se pela raridade. Objetivo: o presente estudo tem como objetivo relatar dois casos de retirada de uma agulha dentária quebrada no espaço pterigomandibular com intensificador de imagem. Material e Métodos: Em ambos os casos, o acidente ocorreu durante um bloqueio do nervo alveolar inferior. Os cirurgiões solicitaram exames de imagem para localizar os objetos por meio de anestesia geral. Na cirurgia, foi realizada uma incisão transoral para retirada da agulha quebrada do espaço pterigomandibular, guiada por um intensificador de imagem. Resultados: Ambas as cirurgias foram um sucesso. As agulhas quebradas foram encontradas rapidamente com o uso do intensificador de imagem, sem complicações pós-operatórias. Conclusão: A correta avaliação da posição dentária fraturada é fundamental para sua remoção. $\mathrm{O}$ uso do intensificador de imagem tem mostrado vantagens, como oferecer imagens dinâmicas transoperatórias rápidas e em diferentes ângulos, trazendo assim uma oportunidade para cirurgias mais tranquilas e com menor risco para o paciente e o operador.

DESCRITORES | Agulha; Fratura; Anestesia local; Imagem.

AUTOR CORRESPONDENTE | • Paulo Rogério Corrêa Couto Centro Universitário Tabosa de Almeida ASCES-UNITA • Rua Laura Rabelo, 71 - Apto. 204A Caruaru, PE, Brazil - 55014-365 E-mail: paulo.couto8522@gmail.com

- Received May 09, 2021 • Accepted June 25, 2021 


\section{INTRODUCTION}

Accidents and complications are elements that can, occasionally, be associated with the procedures performed by the dentist. They can occur during trans-operative or postoperative procedures. Most of them can be bypassed promptly by the professional. However, some cases can be very difficult for the dentist to handle and too inconvenient for the patient. Thus, the specialty in Buccomaxillofacial Surgery and Traumatology is the most involved in the management of patients who present these conditions., ${ }^{1,2}$

Among some accidents related to dental practice, fracture dental needle during local anesthesia is noteworthy due to its rarity. Metal instruments used in clinical practice are susceptible to fatigue. Brokens needle usually occur during anesthetic infiltration. However, this kind of accident has become rare since the introduction of disposable needles that emerged at 1960s. ${ }^{3}$

Nowadays the needle tends to fracture, in most cases, due to the choice of its size and caliber, inadequate technique, and due to the patient's sudden movements during the treatament. In addition, factors involving the psychological condition and the topography of the region to be anesthetized can also be determinants. ${ }^{4}$

When a needle breaks, its removal may be simpler if a fragment part remains visible. However, surgical removal of a broken needle during nerve block in the region that comprises the pterygomandibular space can be difficult due to its proximity to vital anatomical structures in the area. ${ }^{3}$ When it is indicated, the removal of a broken needle must be realized in the safest possible way, avoiding unnecessary risks to the patient, especially if the broken needle is in close contact with important structures. Therefore, the assessment of its correct position is imperative for its removal. ${ }^{5}$

Among the variety of techniques that exist to locate foreign bodies in soft tissues, the image intensifier has several advantages. It is a device that offers images during the operation, in a fast way, providing analysis of the position of the broken needle at different angles, in addition to presenting its relation with the reference surgical instrument. ${ }^{6}$

This work seeks to report the cases of two surgeries to remove a fractured needle using an image intensifier.

\section{CASE REPORT}

\section{Case 1}

A 39-year-old male patient was referred to the Bucomaxillofacial Surgery and Traumatology Service of Hospital Regional do Agreste for removal of a broken needle in the pterygomandibular space on the right side. During the anamnesis, the patient reported that the accident occurred during the attempt to extract the dental element 48. After the accident, the professional tried to remove the needle, but it was unsuccessful.

The clinical examination revealed a slight growth volume in the region, with associated painful symptoms. The patient also had trismus, but there was no infection sign. Imaging exams were requested: face tomography with $3 \mathrm{D}$ reconstruction and panoramic radiography (Figure 1), enabling the observation of an object of approximately $20 \mathrm{~mm}$, compatible with the size of a needle.

Knowing the position of the needle in the pterygomandibular space and the difficulty in locating it during the surgical procedure, it was decided to perform the surgery in a hospital environment, under general anesthesia, with the use of an image intensifier to assist in the trans-operative.

An incision was made along the external oblique line from the third molar lateral region to the first molar right side with delicate detachment of all tissue, perpendicular to the needle plane, especially in the lingual region. After the detachment, the needle was not found. With the image intensifier, model Veradius Philips Medical Systems Nederland B.V, surgical images in region were obtained in the operation, and the precise location of the needle 
was determined (Figure 2). With the support of a curved Halstead forceps, the needle was located and clamped, being removed, without major complications. Soon after the procedure, a radiographic control was made (Figure 3), in which the presence of the radiopaque object was no longer observed. Complications, such as hemorrhage, infection, or paraesthesia were not observed. Currently, the patient is under post-operative followup for 90 days, with no functional complaints.

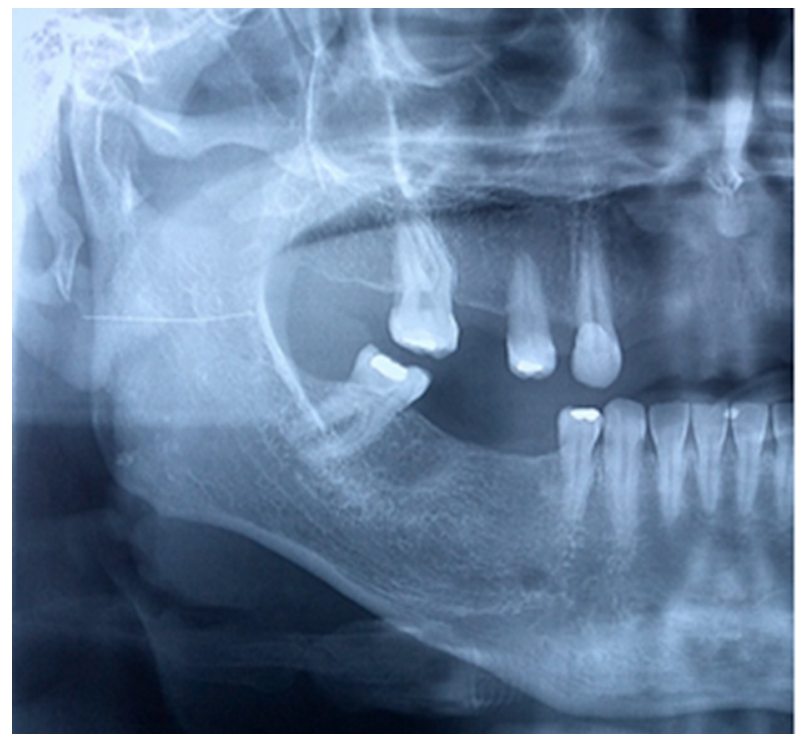

FIGURE 1 Preoperative panoramic radiograph showing the broken needle.

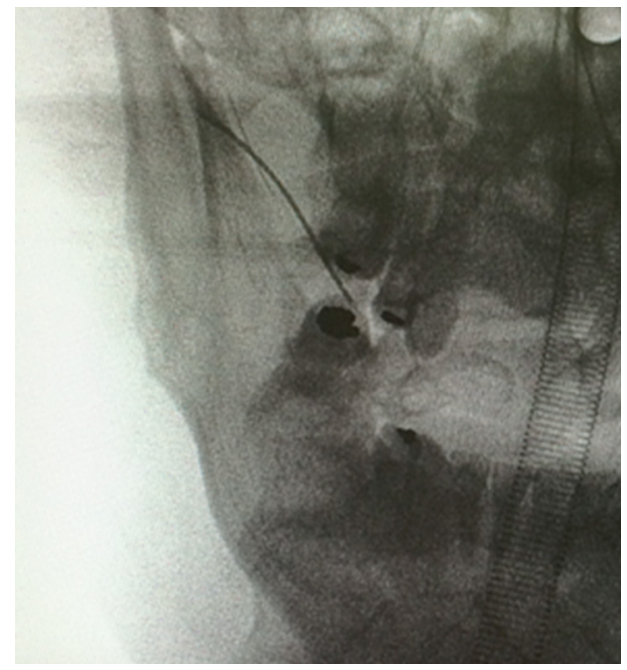

FIGURE 2 | Trans-operative image of the needle (image intensifier).

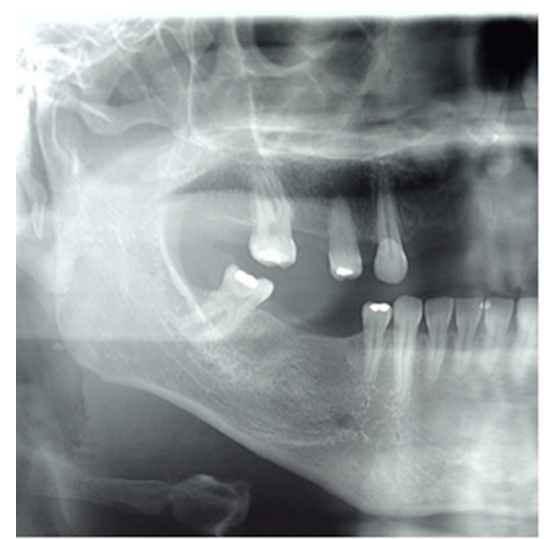

FIGURE 3 | Postoperative panoramic radiography showing the removal of the broken needle.

\section{Case 2}

A 24-year-old male patient was referred to the Oral and Maxillofacial Surgery service of the HRA to do an evaluation of the broken anesthetic needle location and eventual necessity for removal. The accident occurred during anesthetic technique for blocking the left inferior alveolar nerve.

On clinical examination, the patient reported pain and discomfort in the region. Cone beam computed tomography was requested to locate the needle, and the sections showed a hyperdense fragment of approximately $20 \mathrm{~mm}$, located in the left pterygomandibular space (Figure 4).

Due to persistent discomfort, it was decided to remove the needle under general anesthesia with nasotracheal intubation.

During the procedure, the mouth was maintained open and stabilized. A jelco number 18 was inserted into the soft tissues to assist the broken needle location. Images of the region were obtained using the Veradius Philips Medical Systems Nederland B.V.

After spatial location of the fragment, an incision of approximately $4 \mathrm{~cm}$ was made in the buccal mucosa, in the retromolar region, and then a dissection, following the path of the positioned needle. After direct visualization, the needle was removed. The area was sutured with 4.0 resorbable thread, following the hemostatic handling and 
irrigation with saline solution. The patient reacted well, with a satisfactory evolution and was discharged the next day.

After the procedure, a control radiograph (Figure 5) was taken, in which the presence of the radiopaque object was no longer observed. The patient is currently under post-operative follow-up for 90 days, with no functional complaints.

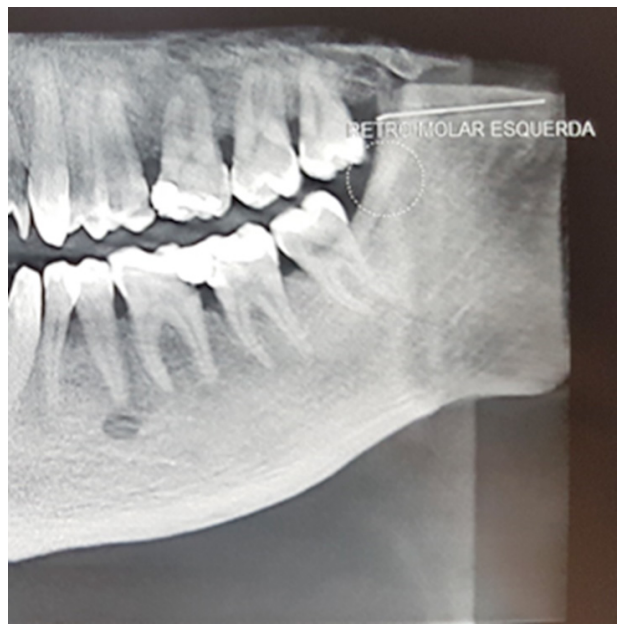

FIGURE 4 | Tomography showing the presence of a broken needle on the left side.

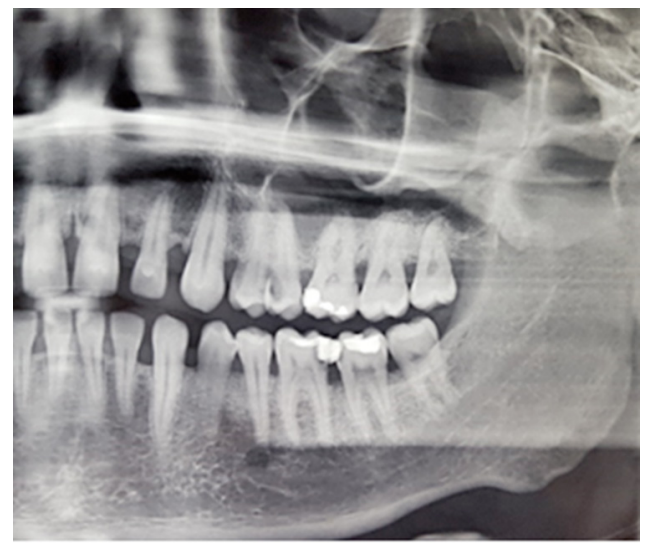

FIGURE 5 | Postoperative panoramic radiograph showing the absence of the broken needle.

\section{DISCUSSION}

Surgical treatment of broken dental needles is a very discussed issue in the literature. Since the introduction of the disposable needles, for the application of anesthetic injections in the oral cavity, the incidence of this accident has decreased significantly. ${ }^{1}$ The literature reports several ways to minimize this accident, such as: guiding the patient not to move during the puncture, not using short needles for inferior alveolar block in adults, not bending the needles before inserting them in the tissue, not inserting the needle body completely to the soft tissue calotte and not using 30-gauge needles for inferior alveolar block in adults or children, giving preference to 27-gauge needles.7

Due to the anxiety and fear that dental treatment causes in a group of people and relating the needs of each case, minimal sedation can be used to avoid disorders during the application of anesthesia, such as sudden movements, and to avoid fractures, especially in infant patients and people with special needs. ${ }^{3}$

Many authors indicate the immediate removal of the broken needle, due to the risk that migration could cause injury to noble structures such as vessels and nerves, which could cause dysesthesias, paresthesias and hemorrhages, as well as to the psychological benefits to the patient. ${ }^{4}$ On the other hand, other authors suggest that this procedure should not be realized when there are no painful symptoms, when taking into consideration the trauma and the complexity of its removal, and because there is the suggestion that the fragment will be surrounded by fibrous tissue. Even so, there are patients who show too much concern about the needle present, even without symptoms. The main indications for removing the fragment in the case reports in question were the pain and trismus generated by the local inflammatory response, in addition to the psychological changes of the patients and the risk of injury to adjacent noble structures. ${ }^{8,9}$

Among the regions of the oral cavity, the maxilla is the least incident. ${ }^{4}$ In contrast, the pterygomandibular space is the most affected local by broken needles in techniques to block the inferior alveolar nerve and the mandibular nerve. This space 
has a very detailed anatomy composed of the medial pterygoid, temporal (superficial and deep fascia) and buccinator muscle, in addition to the inferior alveolar nerve, the lingual nerve and homonymous vessels. Due to this anatomy, the correct location of the fragment by the surgeon becomes a challenge. ${ }^{8}$

For trans-operative localization, the use of computed tomography, metal detectors, conventional radiographs, ultrasonography and fluoroscopy is mentioned. The image exam that most accurately identifies the needle position in relation to adjacent structures is the cone beam computed tomography, contributing to the operative planning. ${ }^{6}$ Ultrasonography is an alternative to assist in removing the needle since it is easy and inexpensive. However, the operator must maintain cautious pressure to displace the fractured object. ${ }^{9}$

In the present case, an image intensifier (fluoroscopy) was used. It is a radiographic method by which the structures can be observed in their dynamics. They are divided into screen fluoroscopy and TV7. In this method, sensors are sensitized by fluoroscopy to generate a virtual image on a video screen. This modality allows a quick and immediate taking of high-quality images and at different angles. ${ }^{10}$ In the cases presented, the use of an image intensifier was essential to locate and remove the needle fragment.

\section{CONCLUSION}

Although it is increasingly rare, a fracture dental needle can occur, and we must be prepared to guide the patient properly. Correct planning, as well as the precise location of the broken needle, are essential for proper treatment. The use of the image intensifier proved to be a viable alternative, facilitating the removal of the needles in the cases presented, consequently reducing the risk of injury to important anatomical structures.

\section{REFERENCES}

1. Prado R, Salim M. Cirurgia bucomaxilofacial: diagnóstico e tratamento. Rio de Janeiro: Guanabara Koogan; 2005.

2. Miloro M, Ghali GE, Larsen PE, Waite PD. Princípios de cirurgia bucomaxilofacial de Peterson. 3rd ed. Rio de Janeiro: Guanabara Koogan; 2016.

3. Lee J, Park MW, Kim MK, Kim SM, Seo KS. The surgical retrieval of a broken dental needle: A case report. J Dent Anesth Pain Med. 2015;15(2):97-100. doi: 10.17245/ jdapm.2015.15.2.97

4. Augello M, von Jackowski J, Dannemann C. Nadelbruch als komplikation bei der intraoralen leitungsanästhesie im unterkiefer. Quintessenz. 2009;60(11):1263-7. doi: 10.5167/ uzh-27509

5. Mohammed H, Shallik N, Barsoum M, Abdulla MA, Dogan $\mathrm{Z}$, Ahmed HH, et al. Dental needle foreign body in the neck: a case report. J Dent Anesth Pain Med. 2020;20(2):83-7. doi: 10.17245/jdapm.2020.20.2.83

6. Perrelli MCG, Arruda JAA, Silva LVO, Barbosa ML, Monteiro JLGC, Cavalcanti TBB. Remoção de agulha fraturada do espaço pterigomandibular utilizando intensificador de imagem: Relato de caso. Braz J Surg Clin Res. 2017;17(2):45-7.

7. Malamed SF, Reed K, Poorsattar S. Needle breakage: incidence and prevention. Dent Clin North Am. 2010;54(4):74556. doi: 10.1016/j.cden.2010.06.013

8. Góngora SS, Hernández JAP. Aplicación imagenológica para la recuperación de una aguja dental rota localizada en el espacio pterigomaxilar. Rev Cubana Estomatol [Preprint]. 2021 [cited 2021 Jan 20]: [10 p.]. Available from: https://bit. ly/3vRoazF doi: 10.13140/RG.2.2.24581.58085

9. You JS, Kim SG, Oh JS, Choi HI, Jih MK. Removal of a fractured needle during inferior alveolar nerve block: two case reports. J Dent Anesth Pain Med. 2017;17(3):225-9. doi: 10.17245/jdapm.2017.17.3.225

10. Schorn L, Sproll C, Depprich R, Kübler NR, Rana M, Singh DD, et al. Navigated recovery of fractured dental injection needles: case report and suggestions for management during pandemic crises. Case Rep Dent. 2021;2021:8820381 doi: $10.1155 / 2021 / 8820381$ 